\title{
Optimalisasi Kelompok Wanita Dalam Upaya Peningkatan Ekonomi Keluarga Kecamatan Bulak - Surabaya
}

\author{
Ignatia Martha $\mathrm{H}^{1^{\star}}$, Nuruni Ika KW${ }^{2}$, Sishadiyati ${ }^{3}$ \\ ${ }^{1-3}$ Universitas Pembangunan Nasional "Veteran" Jawa Timur \\ ${ }^{*}$ Corresponding author \\ E-mail: ignatia.hendrati.ep@upnjatim.ac.id
}

Article History:

Received: 27-10-2020

Revised: 08-02-2021

Accepted: 05-05-2021
Keywords:

\section{Pendahuluan}

Kecamatan Bulak merupakan daerah yang terletak di Pesisir Pantai Kenjeran yang memiliki potensi alam yang berasal dari hasil laut. Rata-rata pekerjaan masyarakat disana adalah sebagai nelayan, sehingga hasil laut yang ada sangat

Produk Olahan Ikan, Inovasi Produk, Pemasaran
Abstract: Kecamatan Bulak merupakan daerah yang terletak di Pesisir Pantai, yang di mana perekonomian masyarakat daerah tersebut sangat mengandalkan pada hasil sektor perikanan. Dengan banyaknya hasil perikanan yang dihasilkan tetapi masyarakat di sana masih belum dapat mengolah hasil perikanan tersebut untuk dijadikan produk olahan yang dapat meningkatkan pendapatan mereka sehingga ekonomi keluarga akan meningkat. Para wanita terutama istri nelayan didaerah tersebut banyak yang berkeinginan untuk membantu para suami mereka untuk mengolah produk makan hasil laut, maka mereka membentuk kelompok wanita yang bernama kelompok usaha wanita CIBUYAM dan SAKKE. Permasalahan yang dihadapi kelompok CIBUYAM ini diantaranya adalah pengolahan yang sederhana, jenis produk yang dihasilkan masih kurang menarik, tampilan produk sederhana, pemasaran yang masih sederhana dan sistem pencatatan keuangan yang masih belum ada. Dalam mewujudkan semua itu tim melakukan kegiatan pendampingan dan pelatihan kepada para wanita atau istri nelayan yang tergabung dalam kelompok usaha wanita CIBUYAM. Pelaksanaan kegiatan pendampingan ini kurang lebih 4 bulan. Di masa pandemi covid-19 ini dilakukan pendampingan dengan cara daring untuk pemberian materi dan untuk praktik dilakukan secara offline dengan tetap menerapkan protokol kesehatan. Tujuan dari kegiatan pendampingan dan pelatihan ini untuk membantu para wanita yang tergabung dalam kelompok usaha CIBUYAM untuk lebih berinovasi, berusaha, dan berkreasi meningkatkan pendapatan ekonomi mereka. Solusi yang diberikan pelatihan mengolah produk makanan yang higenis dan sehat, melakukan diversifikasi produk, mengajarkan dan mempraktekkan bagaimana cara melakukan pemasaran online yang baik dan menarik, serta melatih membuat atau mendesain kemasan dan menyusun laporan keuangan yang sederhana. 
melimpah. Tetapi dengan kurangnya pengetahuan mereka dalam hal pengolahan hasil laut maka nilai jual dari produk tersebut sangat kurang untuk pendapatan mereka. Untuk menambah pendapatan dan kesejahteraan keluarga para istri dan wanita didaerah tersebut tergerak untuk membentuk kelompok wanita yang akhirnya diberi nama Kelompok Usaha Wanita Cibuyam dan Sakke. Dalam konteks kehidupan masyarakat modern dengan karakteristik penduduk yang selalu berorentasi pada pengembangan keilmuan dan teknologi akan berdampak positif terhadap kehidupan masyarakat secara luas (Asse, 2018; Wahyudi \& Sukmasari, 2014).

Kelompok Usaha Wanita ini melakukan kegiatan usahanya dibidang pengolahan hasil laut, ada yang diolah dijadikan makanan ringan, minuman dan asesoris. Mereka memimilih produk mereka diolah dengan bahan dasar ikan dikarenakan ikan merupakan sumber gizi yang baik karena banyak mengandung unsur-unsur yang diperlukan untuk hidup manusia diantaranya protein, lemak, karbohidrat, mineral, dan vitamin yang berbeda dengan manusia. Ikan selain dapat di konsumsi langsung juga dapat diolah menjadi berbagai produk olahan lain. Kelompok Usaha Wanita Cibuyam dan Sakke ini berdiri sejak tahun 2018 dan berkembang sampai dengan sekarang. Masing-masing dari Kelompok Usaha Wanita tersebut memiliki ketua dan anggota, diataranya untuk Kelompok Usaha Wanita Cibuyam diketuai oleh lbu Luluk dengan anggota 10 orang. Sedangkan untuk Kelompok Usaha Wanita Sakke diketuai oleh Ibu Nining dengan jumlah anggota 10 orang. Kedua Kelompok Usaha Wanita tersebut memiliki hasil olahan yag berbeda untuk Kelompok Usaha Wanita Cibuyam memproduksi olahan makanan seperti kerupuk, mie dan bakso. Kelompok Wanita Usaha Sakke memproduksi olahan makanan dan aksesoris .

Kelompok Usaha Wanita Cibuayam dan Sakke ini selama beroperasi memiliki omset usaha dari hasil penjualannya sekitar Rp.1.000.000 - Rp. 2.700.000 per bulan. Jika dilihat dari hasil yang didapatkan keuntungan bersih yang didapatkan sangatlah besar, namun terkadang dalam melakukan proses produksi, kegiatan pemasaran dan pembukuan hasil penjualan yang ada pada kelompok usaha ini masih sangat minim. Hal ini dikarenakan Kelompok Usaha ini masih kurang dalam hal inovasi pengolahan produk, perluasan pemasaran, bentuk kemasan yang masih sangat sederhana dan juga pada pencatatan atau pengelolaan keuangan (Bugis, 2017; Hartati, 2013).

Dengan kurang luasnya area pemasaran, monotonnya produk yang dihasilkan serta kemasan yang kurang menarik atau kekinian, terkadang produk yang ditawarkan kurang laku dipasaran dan kurang bersaing dengan produk - produk hasil olahan ikan lainnya, hal ini disebabkan karena kurangnya pengetahuan mereka tentang cara sistem pemasaran yang lebih luas, jenis-jenis produk yang dihasilkan, kemasan yang dapat menarik pembeli dan juga pada pelaporan keuangan yang sederhana tetapi jelas. Jika dilihat potensi dan kemampuan para ibu-ibu yang tergabung dalam kelompok ini dalam hal pengembangan produk dan pengolahan produk sudah tidak diragukan lagi. Oleh karena itu kami berharap dengan adanya kegiatan Program 
Dimas ini dapat membantu mereka dalam hal pengembangan produk lokal yang dihasilkan lebih baik, dapat diterima di pasaran serta dapat meningkatkan kesejahteraan ekonomi keluarga (Bulan, 2017; Jati \& Yuliansyah, 2017; Shaferi \& Handayani, 2014).

Permasalahan yang sedang dihadapi oleh kelompok usaha wanita Cibuyam dan Sakke, yaitu: 1) proses produksi yang masih sangat sederhana, baik itu dilihat dari cara pembuatan atau produksi, jenis produk yang dihasilkan tidak banyak dan bentuk kemasan yang kurang menarik. 2) fasilitas produksi yang kurang memadai, mengakibatkan proses produksi tidak maksimal. 3) pengembangan sistem pemasaran yang masih dilakukan sederhana, hanya melalui tetangga, teman dan sekitar wilayah produksi saja. 4) sistem pembukuan yang masih sangat sederhana, sehingga tidak rapi dan tidak ada pencatatan cash flow dan laporan laba rugi yang jelas. Dengan melihat kompleksitas permasalahn yang dihadapi oleh Kelompok Usaha Wanita Cibuyam dan Sakke saat ini, maka perlu adanya prioritas permasalahan yang segera diatasi dan sekaligus menjadi tujuan dari kegiatan ini, yaitu : 1) masalah produksi 2) masalah fasilitas produksi 3) masalah manajemen usaha dan keuangan.

\section{Metode Pelaksanaan}

Berdasarkan hasil uraian yang telah dijelaskan sebelumnya bahwa persoalan yang dihadapi oleh Kelompok Usaha Wanita Cibuyam dan Sakke ini perlu untuk segera diselesaikan melalui berbagai cara sesuai dengan identifikasi masalah yang dihadapi. Maka dari itu untuk memperjelas pemecahan masalah yang dihadapi oleh kelompok usaha ini ditentukan pada skala prioritas, dan dalam hal ini kegiatan atau solusi yang akan dilakukan adalah berupa pelatihan dan pendampingan yang dilakukan secara daring atau virtual dengan aspek sebagai berikut: a) pelatihan dan pendampingan pengolahan produksi dan diversifikasi produk; b) pelatihan dan pendampingan packaging, branding dan labeling agar menarik dan memiliki daya saing dengan produk lain; c) pelatihan dan pendampingan aspek pemasaran, untuk dapat memperluas jangkauan pemasaran produk lokal yang marketable; d) pelatihan dan pendampingan dalam pengelolaan keuangan, agar mengetahui besar keuntungan dan kerugian yang didapatkan; e) fasilitas produksi, dengan meberikan alat produksi berupa oven dan mesin chooper. Kegiatan tersebut diperoleh dari hasil pemetaan terhadap potensi yang dimiliki oleh Kelompok Usaha Wanita Cibuyam dan Sakke serta kualifikasi pendampingan, seperti pada Gambar 1. 


\begin{tabular}{|c|c|}
\hline Analisis Situasi & a. Potensi Mitra \\
\hline$\downarrow$ & \\
\hline $\begin{array}{l}\text { Koordinasi dan } \\
\text { Persiapan }\end{array}$ & $\begin{array}{l}\text { Identifikasi Keadaan dan } \\
\text { Kebutuhan }\end{array}$ \\
\hline$\downarrow$ & \\
\hline $\begin{array}{l}\text { Kualifikasi } \\
\text { Pendampingan : } \\
\text { a. Proses Produksi } \\
\text { b. Manajemen Usaha } \\
\text { c. Keuangan } \\
\text { d. Fasilitas }\end{array}$ & $\begin{array}{l}\text { a. Pelatihan dan } \\
\text { Pendampingan pengolahan } \\
\text { produksi dan diversifikasi } \\
\text { produk. } \\
\text { b. Pelatihan dan } \\
\text { pendampingan packaging, } \\
\text { branding, labeling dan } \\
\text { pemasaran. }\end{array}$ \\
\hline
\end{tabular}

Gambar 1. Metode Penyelesaian Mitra

\section{Hasil}

\section{Pelatihan dan Pendampingan Pengolahan Produksi dan Diversifikasi Produk}

Kegiatan pengabdian yang telah dilaksanakan dan Capaian Kegiatan Kelompok CIBUYAM dan SAKKE, kemampuan produksi yang dimiliki sederhana maka mempengaruhi proses produksi. Peralatan yang digunakan masih cukup sederhana hanya menggunakan baskom untuk menguleni tepung untuk membuat bakiak dan mie tulang ikan. Dalam mengatasi hal tersebut TIM PKM melakukan komunikasi dengan mitra untuk cara pengolahan produk yag sehat dan menggunakan teknologi sederhana dan murah. Kami memberikan teknologi pengolahan bakiak dan mie tulang ikan bisa menjadi makanan sehat. Dengan memberikan pengetahuan pada mitra tentang pengolahan tepung tulang ikan yang dibuat sebagai bahan pembuatan mie dengan sawi sebagai pewarnanya untuk dijadikan mie.

Hasilnya rasa lebih enak, gurih dan untuk kesehatan baik tidak kalah dengan perusahaan besar. Keinginan mereka tentang pengolahan mutu produk sehat dan higenis dapat terlihat setelah anggota kelompok mempraktekkan teori yang diberikan pada saat pelatihan proses produksi dengan alat yang kami berikan berupa Mesin chopper Food Proceso, merata sebagai penghalus atau penggiling ikan yang dijadikan sebagai diversifikasi dari produk mereka. Selain mesin chopper kami juga memberikan alat yaitu berupa oven untuk mebuat mie dari tepung ikan dengan adanya diversifikasi produk yang mereka hasilkan adalah bakso dan mie tepung tulang ikan, selain itu juga meningkatkan kapasitas produksi yang sudah naik semula hanya $10 \mathrm{~kg}$ sehari sekarang menjadi $15 \mathrm{~kg}$ sehari. 


\section{IPMM}
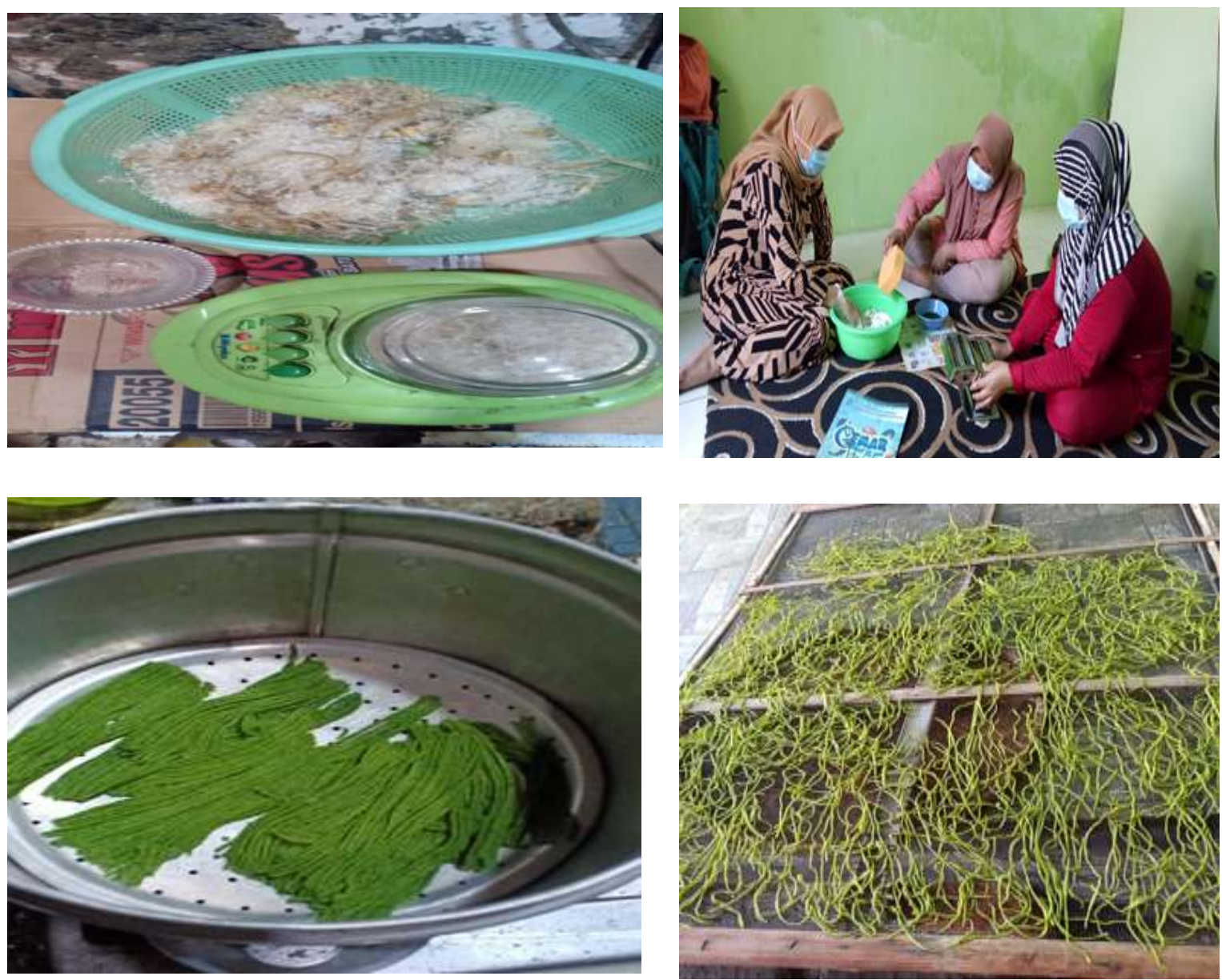

Gambar 2. Kegiatan Diversifikasi Produk Olahan Mie Tulang Ikan
PM: Jurnal Pengabdian kepada Masyarakat Institut Teknologi dan Bisnis Asia Malang Vol. 2, No. 2, November, 2021, pp. 62-72 


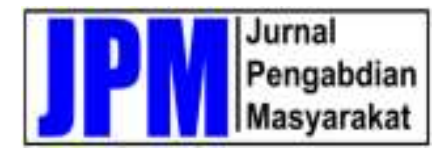

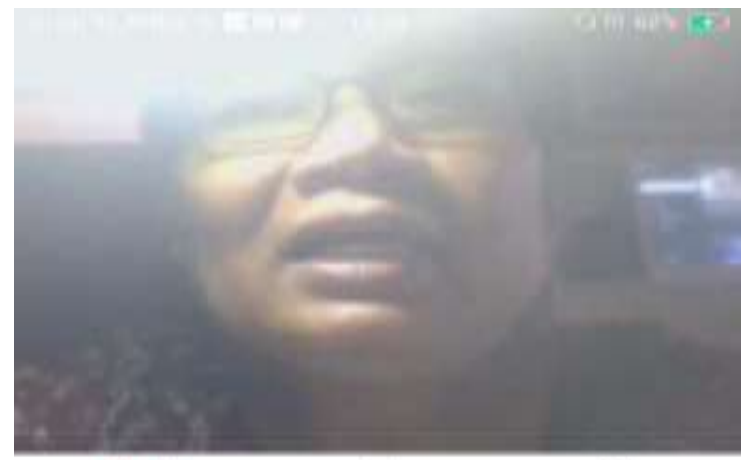

2.. (5)

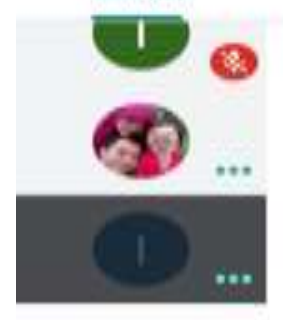

Also in the meeting (1)

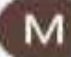

回

lka Nuruni

Ignatio Hendrati

M husnul hotimah
JPM: Jurnal Pengabdian kepada Masyarakat Institut Teknologi dan Bisnis Asia Malang Vol. 2, No. 2, November, 2021, pp. 62-72

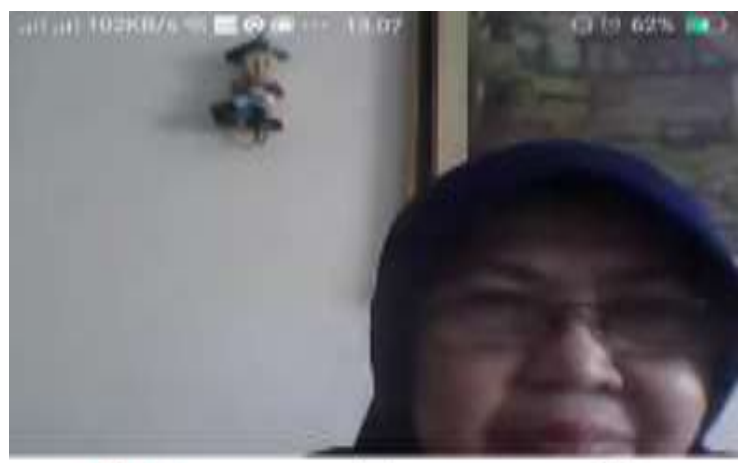

23. (6)

回

(1)

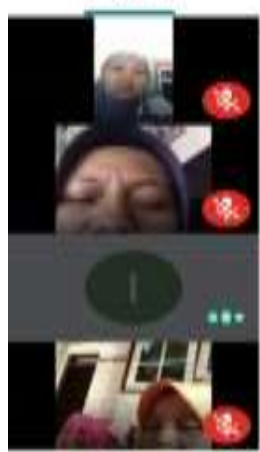

Ratih Sinhadiyati (You)

nining mahelo

ka Nuruni

husmul hotimat

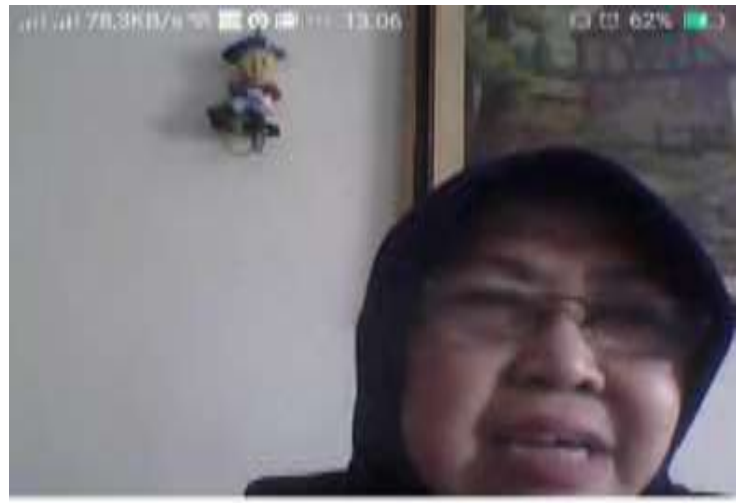

2. (6)

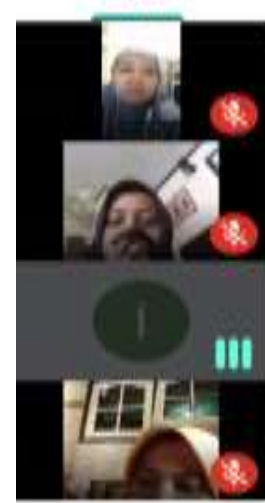

回

Ratih Sishadiyati (You)

nining mahela

Ika Nuruni

husnul hotimah
(1)

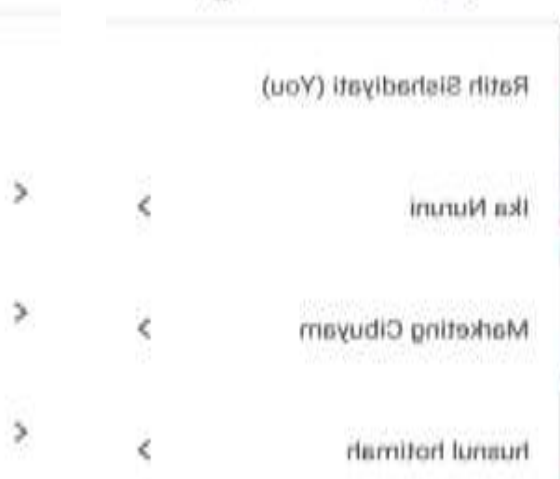

(o) 19

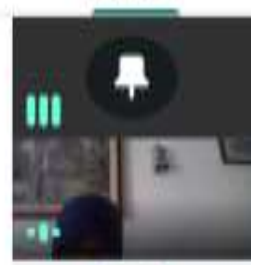

M

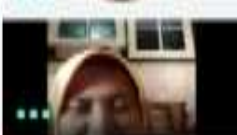

Gambar 3. Pelatihan dan pendampingan Manajemen Usaha 


\section{IPMM}

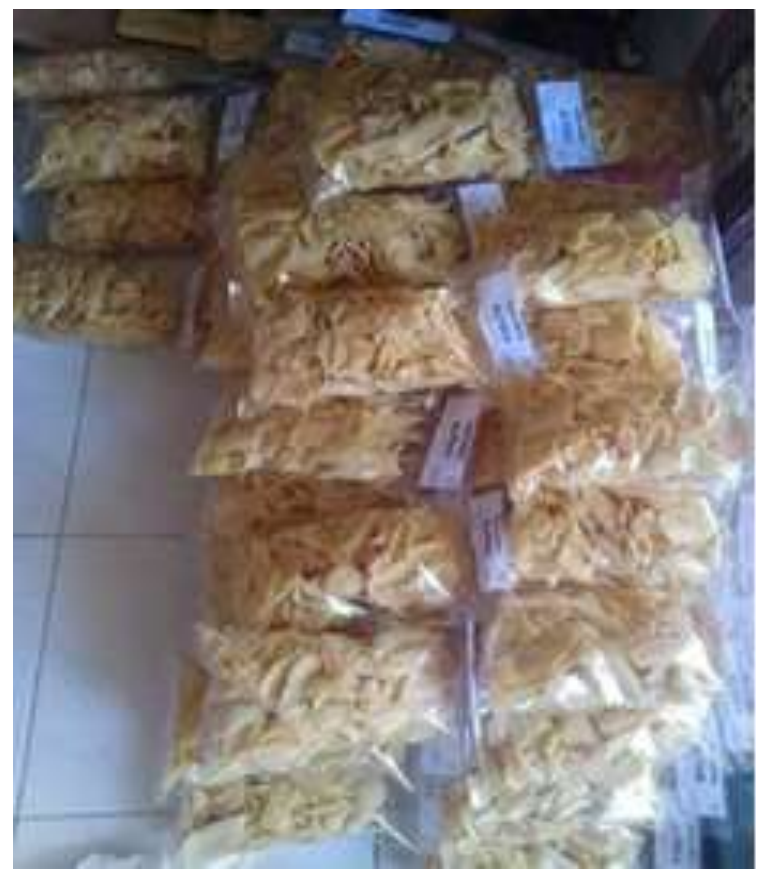

Kemasan sebelum pelatihan
JPM: Jurnal Pengabdian kepada Masyarakat

Institut Teknologi dan Bisnis Asia Malang Vol. 2, No. 2, November, 2021, pp. 62-72

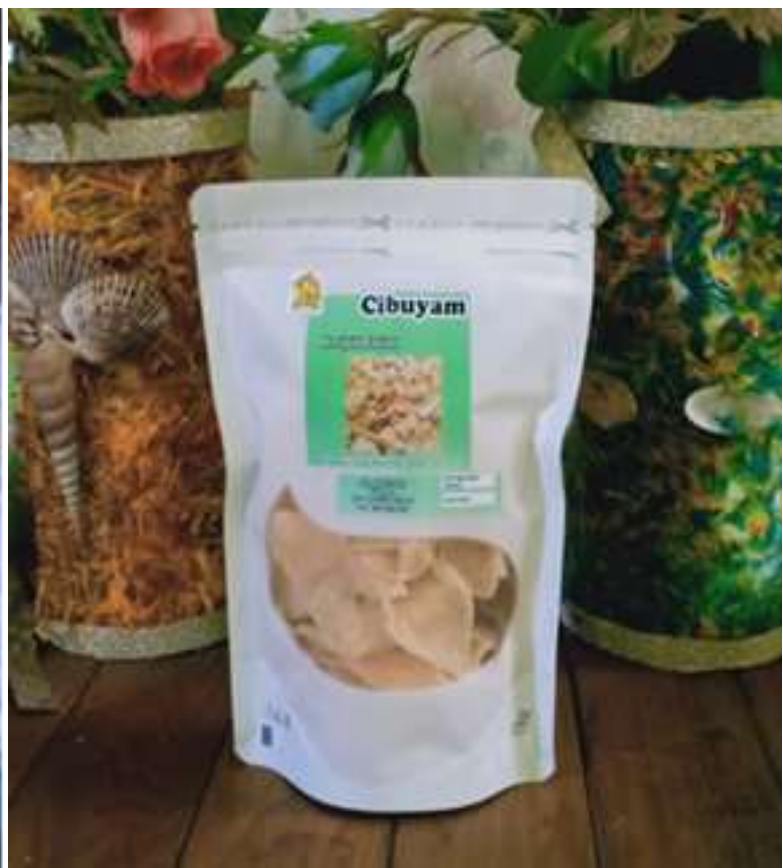

Kemasan sesudah pelatihan

Gambar 4. Hasil Pelatihan dan Pendampingan Packacing, Branding dan Labeling
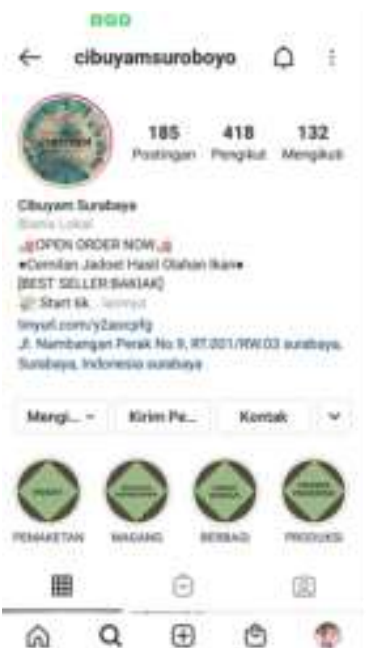

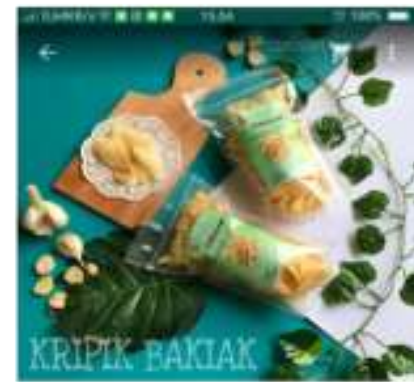

Kripik bakiak

no 1500000
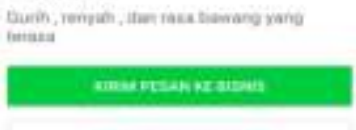

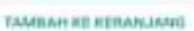

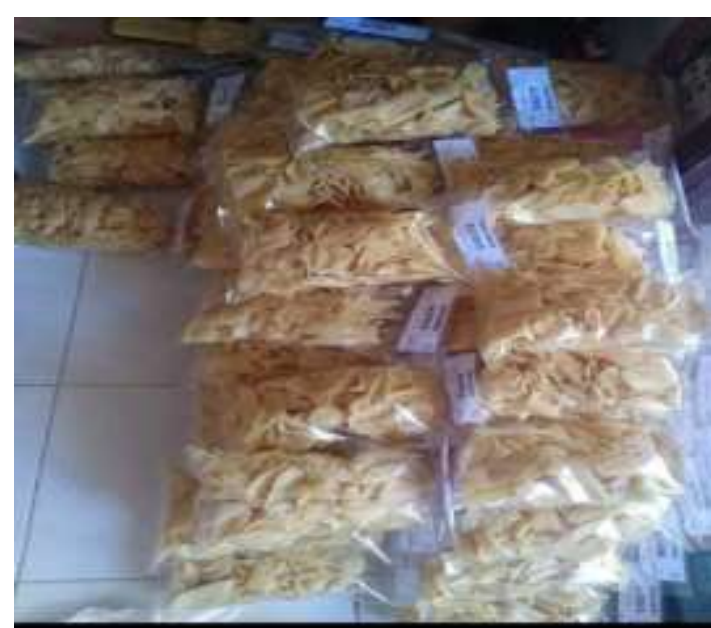

Pendampingan Pemasaran

Pelatihan dan Pendampingan pengetahuan dan ketrampilan Cara Melakukan Pencatatan Keuangan atau Pembukuan dan Kelayakan Usaha.

Ketidaktahuan mereka dalm pengelolaan keuangan maka dilakukan kegiatan pelatihan dalam sistem pengelolaan keuangan yang sederhana dan dapat mudah dimegerti oleh para anggota kelompok CIBUYAM dan kelompok SAKKE yang yang telah dilakukan belum baik dan sistematis. Kelompok ini belum memiliki catatan keuangan yang baik meskipun itu pembukuan yang sederhana. Atas dasar masalah yang ada TIM PKM melakukan kegiatan pelatihan tentang pengelolan keuangan yang 
sederhana dan mudah. Dalam pelatihan ini mereka diajarkan bagaimana cara menghitung HPP dan melakukan pencatatan keuangan yang baik dan benar dalam bentuk sederhana. Diharapkan setelah pelatihan ini kelompok CIBUYAM dan kelompok SAKKE lebih dapat mudah mengelola keuntungan dan keuangan usaha mereka. Pelatihan yang dilakukan ini disambut baik oleh mereka, karena mereka sangat membutuhkan pelatihan keuangan ini. Semua ini ditunjukkan oleh kelompok CIBUYAM dan kelompok SAKKE dalam mengikuti kegiatan pelatihan ini dari awal hingga akhir dan banyak sekali pertanyaan-pertanyaan yang mereka ajukan, apalagi tentang bagaimana menghitung harga jual dan kentungan yang didapatkan dari setiap produk yang dihasilkan.

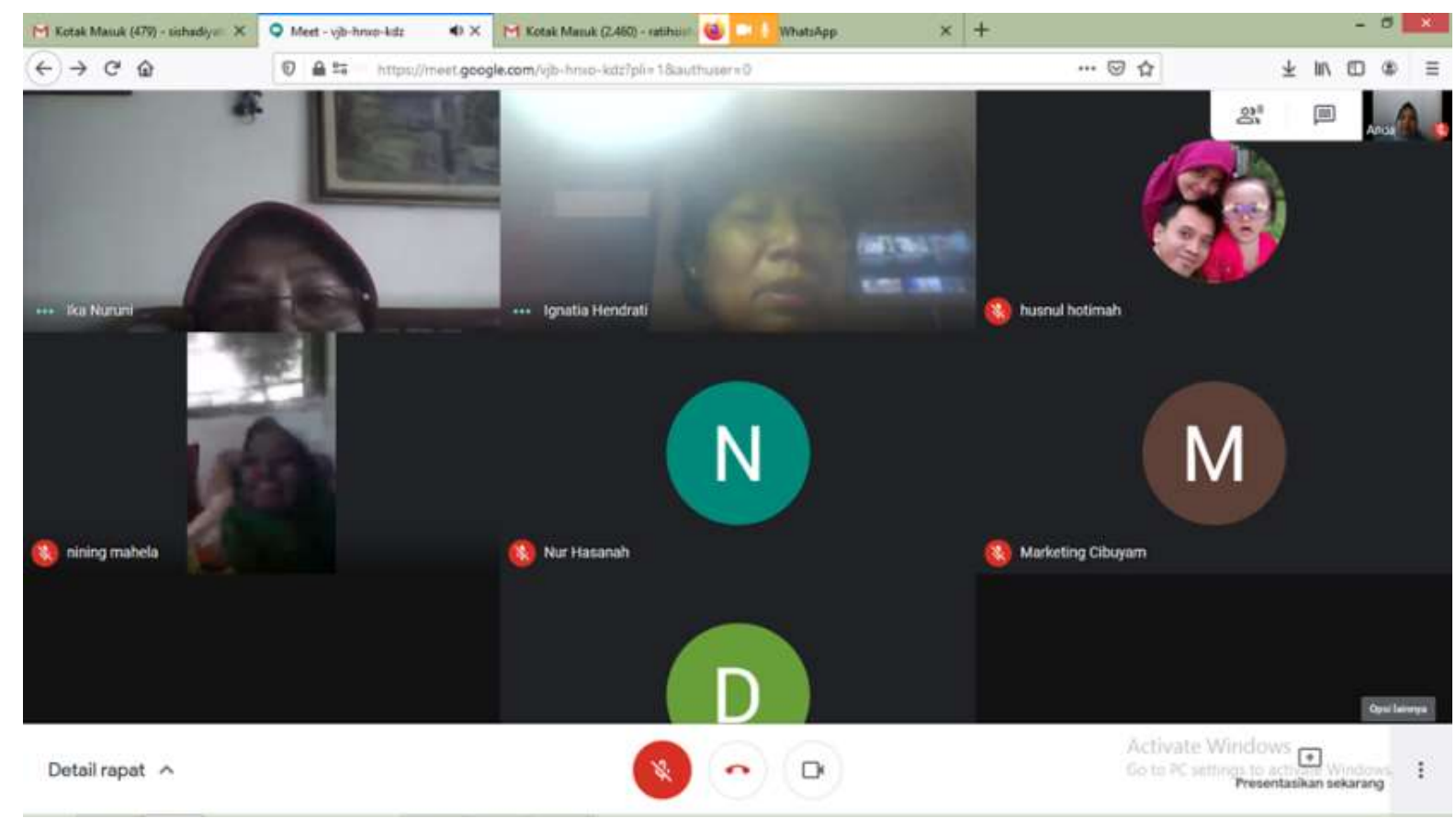

Gambar 6. Pelatihan dan Pendampingan Pengelolaan Keuangan

\section{Fasilitas Produksi}

Selain memberikan pelatihan dan pendampingan dalam kegiatan ini, tim pengabdian ini juga memberikan bantuan alat produksi yang dapat digunakan dalam pengembangan proses produksinya. Diharapkan dengan adanya bantuan alat produksi ini dapat meningkatkan produksi dari Kelompok Usaha Wanita ini dan juga akan meningkatkan pendapatan hasil produksi, sehingga kesejahteraan keluarga akan mengalami peningkatan. Bantuan alat produksi yang diberikan adalah berupa oven dan mesin chooper. Pemberian alat ini disambut baik dan gembira oleh para ibuibu yang teragbung dalam kelompok usaha wanita Cibuyam dan Sakke. 


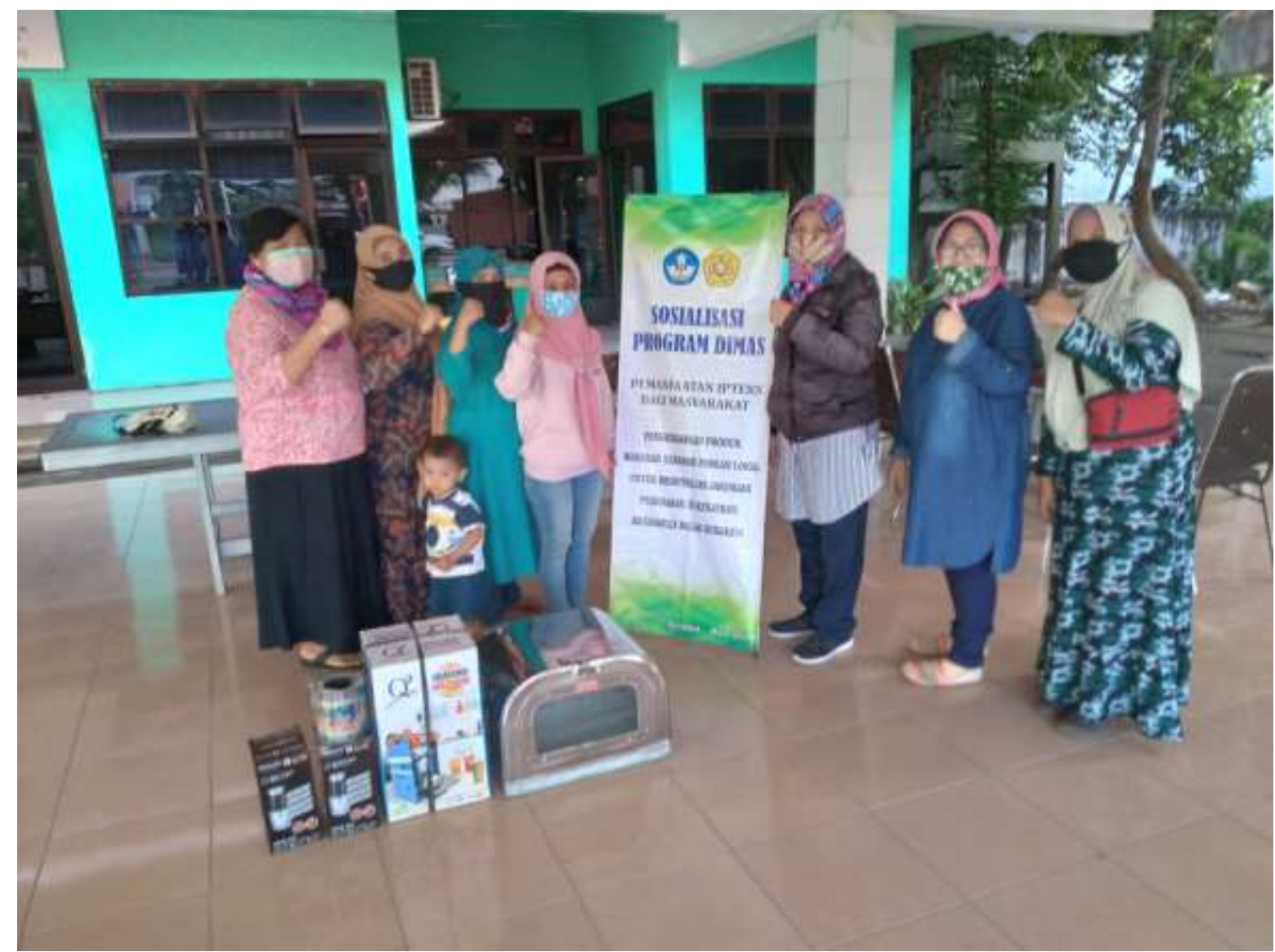

Gambar 7. Foto Penyerahan Barang

\section{Diskusi}

Dalam kegiatan ini kami melakukan pendampingan dan pelatihan serta penyuluhan bagi kelompok ibu-ibu yang tergabung dalam kelompok Cibuyam dan SAKKE. Di kegiatan ini kami memberikan pelatihan dan pendampingan tentang bagaimana mengembangan produk olahan yang berbahan dari ikan dengan cara melakukan diversifikasi produk dari bahan-bahan dasar yang sama dengan produk yang sudah ada. Inovasi produk yang kita berikan adalah dengan membuat mie tulang, dimana bahan dasar pembuatan mie tersebut berasal dari tulang ikan yang dijadikan tepung. Selain itu kta juga memberikan wawasan dan pelatihan pada mereka dalam hal keuangan yatitu dengan mengajari bagaimana perhitungan HPP dan pencatatan pembukuan keuangan yang sederhana dan rapih. Tidak lupa untuk menarik minat para pembeli kita memberikan pelatihan tentang bagaimana cara membuat foto reklame yang baik dan kemasan yang menarik, sehingga dapat meningkatkan penjulan. 


\section{Kesimpulan}

Program pendampingan yang dilakukan oleh tim PKM ini adalah pendampingan pada masyarakat pelaku usaha yang berada di daerah pesisir pantai kenjeran tepatnya di kecamatan bulak yang memiliki potensi produk lokal yang dapat dikembangkan. Berdasarkan dari Kelompok Usaha Wanita yang terbentuk dari para istri-istri nelayan yang ingin meningkatkan kesejahteraan perekonomian keluarga, maka memproduksi produk olahan hasil ikan. Banyak permasalahn yang dihadapi oleh kelompok usaha wanita ini karena kurangnya pengetahuan mereka dalam hal pengelolaan usaha, baik itu dalam hal bidang produk olahan, pemasaran, manajemen usaha dan pengelolaan keuangan.

Dengan adanya pelatihan dan pendampingan ini kelompok usaha wanita ini diberikan pemahaman tentang pengelolaan usaha. Pada prinsipnya Kelompok Usaha Wanita Cibuyam dan Sakke ini sangat konsen pada usaha dalam memperbaiki usahanya serta mengembangkannya. Tinggal tim dalam mendampingi diperlukan upaya dan waktu untuk membinan mereka agar memiliki dan menghasilkan produk yang lebih berdaya saing.

\section{Pengakuan/Acknowledgements}

Pelaksanaan kegiatan PKM ini di danai oleh DIKTI tahun 2020 pada skim Program Kemitraan Masyarakat. Kami mengucapkan terima kasih kepada LPPM UPN "Veteran" Jawa Timur dan Kelompok Wanita CIBUYAM dan SAKKE, serta semua pihak yang telah membantu terlaksananya program PKM ini.

\section{Daftar Referensi}

Asse, R. A. A. (2018). Strategi Pemasaran Online (Studi Kasus Facebook Marketing Warunk Bakso Mas Cingkrank di Makassar). KAREBA: Jurnal IImu Komunikasi, 219-231. https://doi.org/10.31947/kareba.v7i2.6907

Bugis, B. (2017). Faktor-Faktor Yang Mempengaruhi Pengusaha Kecil/ Menengah Tidak Menata Keuangan Sesuai Standar Akuntansi Yang Benar. Mega Aktiva: Jurnal Ekonomi Dan Manajemen, 6(1), 28-38. http://dx.doi.org/10.32833/majem.v6i1.45

Bulan, T. P. L. (2017). Pengaruh Diversifikasi Produk dan Harga terhadap Kepuasan Konsumen pada Juragan Jasmine Langsa | Jurnal Manajemen dan Keuangan. Jurnal Manajemen Dan Keuangan, 6(1), 679-687.

Hartati, S. (2013). Manajemen Keuangan Untuk Usaha Mikro, Kecil dan Menengah. Jurnal Akuntansi \& Investasi, 2(2), 1-6. 
JPM: Jurnal Pengabdian kepada Masyarakat Institut Teknologi dan Bisnis Asia Malang Vol. 2, No. 2, November, 2021, pp. 62-72

Jati, W., \& Yuliansyah, H. (2017). Pengaruh Strategi Pemasaran Online (Online Marketing Strategy) Terhadap Minat Beli Konsumen (Studi Kasus Pada Toko Online Shop Azzam Store). Jurnal Pemasaran Kompetitif, 1(1), 127-138. http://dx.doi.org/10.32493/jpkpk.v1i01.679

Shaferi, I., \& Handayani, S. R. (2014). Identifikasi Pengelolaan Keuangan Terhadap Peluang Usaha Online. Sustainable Competitive Advantage (SCA), 4(1), Article 1. http://www.jp.feb.unsoed.ac.id/index.php/sca-1/article/view/722

Wahyudi, H. S., \& Sukmasari, M. P. (2014). Teknologi dan kehidupan masyarakat. Jurnal Analisa Sosiologi, 3(1), 13-24. 